\title{
Recent Developments in Home Equity Lending
}

Glenn B. Canner, Thomas A. Durkin, and Charles A. Luckett, of the Board's Division of Research and Statistics, prepared this article.

The equity that has accumulated in homes is one of the largest components of U.S. household wealth. But unlike many other types of assets, home equity is not highly liquid - it cannot, for instance, be readily used to purchase goods or services or to repay debt. Home equity is, however, a widely accepted form of collateral for credit, and in recent years, homeowners have borrowed large amounts against the equity in their homes.

Home equity borrowing is frequently used as a substitute for consumer credit, either to finance new consumption expenditures or pay down outstanding consumer debt. This substitution generally lowers the interest expense of carrying debt and may further reduce monthly debt service payments in the short run by lengthening loan maturities. Of course, by replacing what is often unsecured debt with homesecured debt, borrowers become exposed to the risk of more severe consequences in the event of some financial setback that might impair their ability to service their debts.

In view of the growing importance of home equity credit in household finances, the Federal Reserve has for a number of years closely followed developments in the home equity lending market. The Federal Reserve obtains information from monthly and quarterly reports from banks and other lending institutions, and it has participated in several nationwide surveys of household finances, including some that focus on the use of home equity loans. ${ }^{1}$

1. See Thomas A. Durkin and Gregory E. Elliehausen, 1977 Consumer Credit Survey (Board of Governors of the Federal Reserve System, 1978); Robert B. Avery, Gregory E. Elliehausen, Glenn B. Canner, and Thomas A. Gustafson, "Survey of Consumer Finances, 1983," Federal Reserve Bulletin, vol. 70 (September 1984), pp. 67992; Glenn B. Canner, James T. Fergus, and Charles A. Luckett, "Home Equity Lines of Credit," Federal Reserve Bulletin, vol. 74 (June 1988), pp. 361-72; Glenn B. Canner, Charles A. Luckett, and Thomas A. Durkin, "Home Equity Lending," Federal Reserve Bulletin, vol. 75 (May 1989), pp. 333-44; Glenn B. Canner, Thomas A. Durkin, and Charles A. Luckett, "Home Equity Lending: Evidence from Recent Surveys," Federal Reserve Bulletin, vol. 80 (July 1994), pp. 571-83.
Most recently, to learn more about the current status of home equity lending, the Federal Reserve participated in the May through October 1997 Surveys of Consumers, a monthly canvass conducted by the Survey Research Center of the University of Michigan (for further details on the surveys, see the appendix). This article presents findings from those surveys and from other sources of information on home equity lending.

\section{BACKGROUND}

Home equity credit is only one way homeowners can convert their home equity (which is the difference between the home's market value and its outstanding mortgage debt) into spendable funds. Homeowners may sell their homes and purchase less expensive property or become renters. Alternatively, a homeowner may refinance an existing mortgage and borrow more than is required to pay off the old loan plus closing costs. ${ }^{2}$ The availability of these alternatives greatly influences the home equity credit market. Refinancings, which are apt to occur in large volume when interest rates fall, particularly affect home equity lending because homeowners often pay off other debts, including home equity loans, when they refinance an existing purchase-money mortgage. ${ }^{3}$

Home equity credit typically takes either of two forms. One, referred to here as a "traditional home equity loan," is a closed-end loan extended for a specified length of time and generally requires repayment of interest and principal in equal monthly installments. Such loans typically are second mortgages. Interest rates on these loans are ordinarily fixed for the life of the loan. The second form, a

2. In recent years, another option, the so-called reverse mortgage, has become available. These mortgages allow homeowners with equity in their homes to take out mortgages that pay the homeowner, typically a retired person, a monthly amount without requiring immediate repayment. Repayment occurs at a specified time in the future, ordinarily when the house is sold.

3. See Glenn B. Canner, Thomas A. Durkin, and Charles A. Luckett, "Mortgage Refinancing," Federal Reserve Bulletin, vol. 76 (August 1990), pp. 604-12; and Joseph Asher, "The Push is on for Home Equity Business," ABA Banking Journal (April 1995), pp. 56-59. 
"home equity line of credit," is a revolving account that permits borrowing from time to time at the account holder's discretion up to the amount of the credit line. Home equity lines of credit typically have more flexible repayment schedules than traditional home equity loans, and the interest rates on most of these loans vary with changes in an index rate, such as the prime rate. ${ }^{4}$ The majority of credit lines are also of second-mortgage status, but they would be first liens for homeowners who had no other mortgage debt outstanding when the lines were established. The survey results indicate that the users of these two distinct types of home equity products themselves differ in measurable ways.

At the end of 1997, the outstanding home equity debt of U.S. homeowners was an estimated \$420 billion, an amount that is fully one-third the size of nonmortgage consumer debt. Home equity lenders have been expanding their product offerings and changing underwriting standards as they have gained experience with the market. Lenders have continued to promote this product aggressively by waiving closing costs and other fees, offering low introductory interest rates, and increasing the acceptable limits on loan-to-value ratios.

\section{HOLDINGS OF HOME EQUITY LOANS}

Although households have used home equity loans for many years, their appeal for homeowners was heightened by the Tax Reform Act of 1986, which mandated the phaseout of federal income tax deductions for interest paid on nonmortgage consumer debt. With this change in tax law, mortgage debt (on which the interest remained tax deductible) became more attractive to consumers for funding expenditures that previously were financed through auto loans, credit cards, or personal cash loans.

The favorable tax treatment of debt secured by homes, however, is only one reason for the popularity of home equity loans (table 1). Consumers also frequently cite the relatively low interest rates on home equity loans compared with most other forms of consumer credit as another important advantage.

For some homeowners, particularly those who encounter significant disruptions in income (for

4. Industry surveys find that well over 90 percent of home equity lines of credit have variable rates, while the rates on only a small proportion of traditional home equity loans are variable. See Richard F. Demong and John H. Lindgren, Jr., "Home Equity Lending: Survey Reveals Bright Picture," Journal of Retail Banking, vol. 17 (Spring 1995), pp. 37-48.
1. Percentage of home equity credit users citing advantages of such credit over other types of credit, by type of home equity credit, 1997

\begin{tabular}{|c|c|c|}
\hline Advantage & $\begin{array}{l}\text { Line of } \\
\text { credit }\end{array}$ & $\begin{array}{l}\text { Traditional } \\
\text { loan }\end{array}$ \\
\hline Low interest rate & 35 & 49 \\
\hline Easy to get $\ldots . .$. & 20 & 12 \\
\hline Tax advantage .... & 38 & 40 \\
\hline Convenient to use ${ }^{1} \ldots \ldots \ldots \ldots \ldots$ & 43 & 1 \\
\hline Can defer repayment of principal & 4 & \\
\hline Other $^{2} \ldots \ldots \ldots \ldots \ldots$ & 14 & 22 \\
\hline
\end{tabular}

NoTE. Data have been weighted to ensure the representativeness of the sample. Percentages sum to more than 100 percent because respondents were allowed to cite up to two advantages for each type of credit.

* Less than 0.5 percent.

1. Immediate access to funds and other responses indicating that convenience was an advantage.

2. Ability to borrow a large amount, absence of closing costs, ability to consolidate debts, and miscellaneous other responses.

Source. Surveys of Consumers, 1997. Here and in the following tables, Surveys of Consumers refers to the monthly series by that name conducted by the Survey Research Center of the University of Michigan. See text appendix for details of the survey.

example, job loss) or large and perhaps unexpected claims on their income (for example, large medical expenses), drawing upon the equity in their homes may be the only means available to obtain needed funds. Access to a home equity loan (a secured debt) may be particularly important for such households if they have had difficulty meeting loan obligations in the past, because their ability to obtain other (unsecured) types of credit is likely to be severely limited.

Before the mid-1980s, nearly all home equity borrowing was of the traditional type. Since then, home equity lines of credit have grown substantially in popularity. Although relatively attractive interest rates and tax advantages characterize both types of loan, the ability to draw money as needed has proved to be a particularly attractive feature of home equity lines of credit.

Surveys of households provide an opportunity to trace the extent of home equity borrowing over time. Surveys sponsored by the Federal Reserve and others indicate that about 5 percent of homeowners had home equity debt in 1977 (table 2). By 1983, the proportion had risen to 7 percent. Following the 1986 tax changes, lenders began to promote home equity lending aggressively and greatly expanded the availability of such credit. By the second half of 1988, the proportion of homeowners with home equity loans had risen substantially, to 11 percent, and was about equally divided between home equity lines of credit and traditional home equity loans.

The proportion of homeowners with home equity loans continued to grow after 1988, reaching 13 percent in 1993-94. The 1997 survey indicated little further change in this proportion, but because of increases in both the rate of homeownership and the 
2. Percentage of homeowners with home equity credit, by type of credit, selected years, 1977-97

\begin{tabular}{c|c|c|c|c|c}
\hline Type & 1977 & 1983 & 1988 & $1993-94$ & 1997 \\
\hline Any type $\ldots \ldots \ldots \ldots \ldots$ & $\mathbf{5}$ & $\mathbf{7}$ & $\mathbf{1 1}$ & $\mathbf{1 3}$ & $\mathbf{1 3}$ \\
Line of credit $\ldots \ldots \ldots \ldots$ & n.a. & n.a. & 6 & 8 & 8 \\
Traditional loan $\ldots \ldots \ldots .$. & n.a. & n.a. & 5 & 5 & 5 \\
\hline
\end{tabular}

Note. Data have been weighted to ensure the representativeness of the sample. Between 1988 (the first year for which the data are available) and 1997, fewer than $1 / 2$ percent of homeowners had both types of home equity credit. n.a. Not available.

SourCE. 1977 Consumer Credit Survey; 1983 Survey of Consumer Finances; Surveys of Consumers, 1988, 1993-94, and 1997.

number of households, the number of households with a home equity loan increased about 10 percent from 1993-94 to 1997.

In contrast to the pattern of account holding observed in 1988, both the 1993-94 and 1997 surveys found that home equity lines of credit were more prevalent ( 8 percent of homeowners had them in 1997) than traditional home equity loans (5 percent of homeowners). Taken together, roughly 9 million households had home equity loans in 1997.

The 1990s have seen several periods of extensive refinancing activity, particularly in 1992 and 1993. During those years, when interest rates on home mortgages fell substantially, millions of homeowners took advantage of the lower rates; in the process of refinancing their first mortgage, some rolled the outstanding balances on their home equity loans into the new loan. As a consequence, the proportions of homeowners with home equity loans found in the 1993-94 and 1997 surveys were likely smaller than they would have been otherwise.

A second factor that has likely held down the proportion of households with home equity loans in recent years has been an increase in the share of home purchase loans with high loan-to-value ratios (LTVs) - loans in which the amount borrowed is more than 90 percent of the appraised value of the property. Between 1989 and 1996, the proportion of conventional mortgages with high LTVs more than tripled, from 7 percent to 25 percent. ${ }^{5}$ An increasing incidence of home purchase loans with high LTVs means relatively more homeowners have little home equity available to support home equity borrowing.

\section{SOURCES OF HOME EQUITY LOANS}

Many types of financial institutions extend home equity loans. Before the mid-1970s, home equity loans were most frequently supplied by consumer finance companies, second mortgage companies, and individuals. Depository institutions-commercial banks, savings banks, savings and loan associations, and credit unions-were the source of only about two-fifths of these loans. ${ }^{6}$ Today, commercial banks are the primary source of home equity loans, although the other types of depositories as well as finance companies have significant market shares (table 3 ).

Household surveys indicate some specialization among lenders in the type of home equity credit they supply. Consumer finance companies continue to be a significant source of traditional home equity loans while playing a much smaller role in the market for home equity lines of credit. Survey evidence indicates that finance companies account for about 25 percent of traditional home equity loans but only about 7 percent of the home equity line of credit market. More than 90 percent of homeowners with home equity lines of credit obtained them from depository institutions, most frequently commercial banks.

5. Terms on Conventional Home Mortgages, monthly release, table 1 (Federal Housing Finance Board).

6. See Durkin and Elliehausen, "1977 Consumer Credit Survey," p. 92.

3. Home equity loans, grouped by type and distributed by source, selected years, 1988-97

Percent

\begin{tabular}{|c|c|c|c|c|c|c|}
\hline \multirow{2}{*}{ Source } & \multicolumn{2}{|c|}{1988} & \multicolumn{2}{|c|}{ 1993-94 } & \multicolumn{2}{|c|}{1997} \\
\hline & Lines of credit & Traditional loans & Lines of credit & Traditional loans & Lines of credit & Traditional loans \\
\hline Commercial banks & 54 & 33 & 60 & 29 & 61 & 44 \\
\hline Savings institutions ${ }^{1}$ & 31 & 27 & 21 & 30 & 16 & 20 \\
\hline Credit unions ....... & 11 & 8 & 13 & 11 & 16 & 13 \\
\hline Other creditors ${ }^{2}$ & 4 & 32 & 7 & 29 & 7 & 24 \\
\hline Total & 100 & 100 & 100 & 100 & 100 & 100 \\
\hline
\end{tabular}

Note. Percentages are based on numbers of loans or lines of credit. Data have been weighted to ensure the representativeness of the sample. In this and subsequent tables, components may not sum to totals because of rounding.

1. Savings banks and savings and loan associations.

2. Finance and loan companies, brokerage firms, mortgage companies, and individuals.

SourcE. Surveys of Consumers, 1988, 1993-94, and 1997. 
Several factors help explain the specialization among lending institutions. The larger role of finance companies in the traditional home equity loan market may in part reflect long-time customer relationships as well as limits on the services they provide. Because finance companies typically do not offer deposit services (except, in some cases, through affiliated depository institutions), they are less well suited to offering credit accounts that the borrower can draw down by check, a feature of virtually all home equity lines of credit. Also, finance companies tend to serve a somewhat younger clientele with relatively lower incomes and substantially smaller amounts of home equity. ${ }^{7}$ Lenders often prefer to exercise tighter control over the credit use of such customers by granting them loans of specified amounts with predetermined payment schedules.

Although commercial banks are the predominant source of home equity lines of credit, not all banks offer this type of loan. As of September 1997, 53 percent of all U.S. commercial banks held outstanding balances on home equity lines of credit (table 4). A much larger proportion, 81 percent, held traditional home equity loans.

Home equity lines of credit are more complex to administer than are traditional home equity loans; consequently, large banks are more likely than smaller banks to offer lines of credit. The vast majority of commercial banks with assets exceeding $\$ 250$ million offered home equity lines of credit in 1997, whereas only 28 percent of those with assets of less than $\$ 50$ million did so. The pattern is different

7. According to the 1997 survey, the median family income of home equity borrowers at finance companies was $\$ 51,000$, compared with $\$ 55,000$ at depository institutions. The median home equity of finance company borrowers was $\$ 36,000$, compared with $\$ 68,000$ for borrowers from depository institutions (data not shown in tables).

4. Percentage of U.S. commercial banks with outstanding home equity credit, 1997, by type of credit

\begin{tabular}{|c|c|c|}
\hline $\begin{array}{l}\text { Assets of banks } \\
\text { (millions of dollars) }\end{array}$ & Lines of credit & Traditional loans \\
\hline Less than $50 \ldots \ldots$ & 28 & 66 \\
\hline $50-99 \ldots \ldots$ & 55 & 88 \\
\hline $100-249$ & 74 & 94 \\
\hline $250-499$ & 83 & 93 \\
\hline 500-999. & 89 & 97 \\
\hline 1,000 or more . & 85 & 88 \\
\hline All banks . & 53 & 81 \\
\hline Мемо & & \\
\hline Lines of credit in use (percent) ${ }^{1}$ & 51 & $\cdots$ \\
\hline
\end{tabular}

1. Calculated by summing the outstanding balances under home equity lines of credit and dividing by that sum plus the amount of unused lines of credit available to account holders.

. Not applicable.

SOURCE. Reports of Condition and Income, September 30, 1997. for traditional home equity loans, with most banks at all asset levels offering such loans.

\section{USERS AND USES OF HOME EQUITY CREDIT}

As a group, homeowners with home equity credit have economic and demographic characteristics that set them apart from other homeowners. In general, home equity borrowers are relatively sophisticated and financially well off, although considerable diversity is found among them (see box "Consumer Knowledge and Satisfaction Regarding Home Equity Credit"). Moreover, important differences exist between holders of credit lines and users of traditional home equity loans. Differences among holders of each product-in their financial and demographic characteristics, in their uses of borrowed funds, and in their perceptions of the advantages of the two products-suggest that borrowers may not consider them to be close substitutes.

\section{Characteristics of Holders of Home Equity Credit}

Homeowners, who account for nearly two-thirds of all households, vary widely in their demographic characteristics and financial circumstances. Homeowners with no mortgage debt tend to be older individuals, in many cases retired; and, although they typically have relatively large amounts of home equity, they also tend to have lower incomes (table 5).

Households who have a home equity line of credit typically own relatively expensive homes, have higher incomes, and have substantially more equity in their homes than most other homeowners, including those who have a traditional home equity loan. In 1997 , median household income was $\$ 60,000$ for homeowners with home equity credit lines, $\$ 50,000$ for those with traditional home equity loans, and $\$ 47,500$ for those with first mortgages only. ${ }^{8}$ The median amount of home equity among credit line holders was $\$ 76,000$, compared with only $\$ 35,000$ for those with traditional home equity loans and $\$ 43,000$ for those with only a first mortgage. Those

8. Surveys of lending institutions also reveal substantial differences between the income profiles of homeowners with home equity credit lines and those with traditional home equity loans. John H. Lindgren, Jr., and Richard F. Demong, Home Equity Loan Study: An Analysis of the Year-End 1996 Survey (Consumer Bankers Association, 1997); and Demong and Lindgren, "Home Equity Lending," pp. $42-43$. 


\section{Consumer Knowledge and Satisfaction Regarding Home Equity Credit}

The 1997 survey repeated a series of questions from earlier surveys to update available information about consumers' understanding of their home equity loans, their searches for information, and their views of some associated consumer protections. For comparison, the survey also asked similar questions of users of other forms of consumer installment credit.

Initial questions focused on the homeowner's understanding of the creditor's security interest in the home. As in the 1993-94 survey, almost all users of home equity credit surveyed in 1997 indicated that the lender explained, or that they already had known, that their home served as security for the loan (table). Most consumers also said they knew of, or recalled the lender's having informed them of, their right to cancel the transaction up to three days after the closing date (a right that is a provision of the Truth in Lending Act).

Survey respondents cited many actions that a lender might take if they missed payments, including sending late-payment notices, assessing late-payment fees, working out a revised payment schedule, contacting a collection agency, and foreclosing on their home. When asked what they thought the worst thing a lender could do if they missed several payments, most respondents ( 85 percent, not shown in the table) said that the lender could foreclose on the loan. Thus, although virtually all home equity account holders recognized that a lien had been placed on their property, not all believed that foreclosure and loss of the property was the most severe possible outcome, perhaps indicating that some borrowers have substantial other resources available to meet obligations.

Another group of questions updated survey evidence about efforts of home equity credit account holders to gather information before opening an account: About half searched for information about home equity credit before opening the account, somewhat more than the proportion of installment credit users. Most of the information searches involved calling or visiting one or more institutions to ask about interest rates. Some information searchers consulted friends, relatives, and financial advisers, and some consulted published sources. Most of the searchers said they were able to get all the information they were looking for, and a few more said they were able to obtain at least some of the information they sought. ${ }^{1}$

Most surveyed holders of home equity credit accounts specifically recalled receiving a Truth in Lending (TIL)

1. These questions were asked only of those who had obtained home equity credit or installment credit. The survey did not address the experience of any potential borrowers who sought home equity credit but did not obtain it or who chose not to apply after receiving information. disclosure statement, and more than 90 percent of that group had saved the statement. ${ }^{2}$ The proportion that recalled having received a Truth in Lending statement was slightly lower for users of traditional home equity loans, although the proportion of this group that had saved the statement, at 97 percent, was slightly higher. About 70 percent of those who recalled having received a TIL statement reported that it had been helpful to them in some way, but only a small proportion said that the TIL statement had affected their decision to use credit.

A final set of questions concerned consumer satisfaction with their home equity or installment credit. Satisfaction levels exceeded 90 percent for each of the types of credit. Among the small percentage of respondents who were dissatisfied, most complaints concerned the interest rate on the loan.

2. Under the Truth in Lending Act, lenders must give disclosure statements to potential borrowers. The statements include information about key terms related to the transaction, including the annual percentage rate.

Consumer knowledge and satisfaction regarding home equity credit and installment credit, by type of credit, 1997

Percent

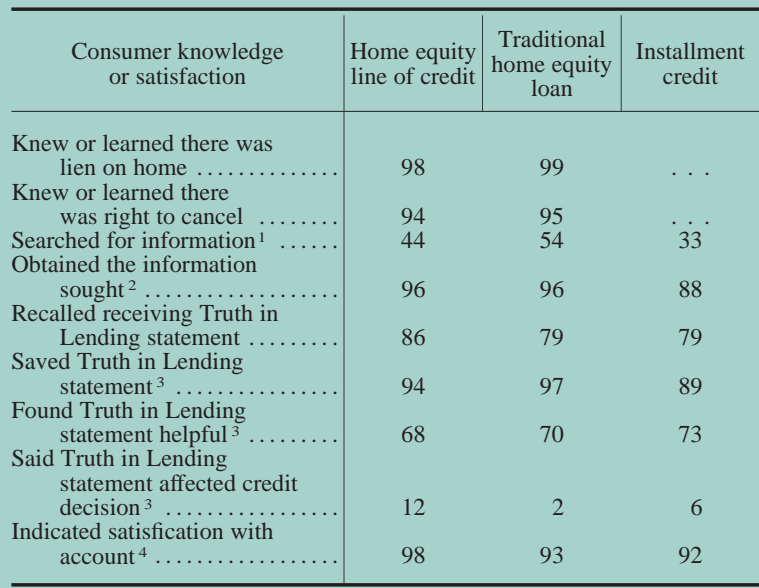

Note. Percentages are for holders of the indicated type of credit. Data have been weighted to ensure the representativeness of the sample.

1. Searched for information about other creditors or credit terms before obtaining credit.

2. Proportion of those who "searched for information."

3. Proportion of those who "recalled receiving Truth in Lending statement."

4. Respondents who said they were "very satisfied" or "somewhat satisfied" with account.

SOURCE. Surveys of Consumers, 1997. with home equity lines of credit also tend to be better educated than other homeowners.

Further evidence of differences in demographic and financial circumstances among homeowners can be seen when homeowners with different debt status are grouped by level of income, home equity, and other characteristics (table 6). The relative affluence of those with home equity lines of credit is apparent 
5. Characteristics of homeowners, by debt status, 1997

\begin{tabular}{|c|c|c|c|c|c|c|c|c|c|c|}
\hline \multirow{2}{*}{$\begin{array}{l}\text { Homeowner } \\
\text { debt status }\end{array}$} & \multirow{2}{*}{$\begin{array}{l}\text { Proportion } \\
\text { of home- } \\
\text { owners } \\
\text { (percent) }\end{array}$} & \multicolumn{2}{|c|}{$\begin{array}{l}\text { Market value of } \\
\text { home (dollars) }\end{array}$} & \multicolumn{2}{|c|}{$\begin{array}{l}\text { Home equity }{ }^{1} \\
\text { (dollars) }\end{array}$} & \multicolumn{2}{|c|}{$\begin{array}{l}1997 \text { family income } \\
\text { (dollars) }\end{array}$} & \multirow{2}{*}{$\begin{array}{l}\text { Age }^{2} \\
\text { (median } \\
\text { years) }\end{array}$} & \multirow{2}{*}{$\begin{array}{l}\text { Education }^{2} \\
\text { (median } \\
\text { grade } \\
\text { completed) }\end{array}$} & \multirow{2}{*}{$\begin{array}{c}\text { Nonwhite } \\
\text { and } \\
\text { Hispanic }^{3} \\
\text { (percent) }\end{array}$} \\
\hline & & Mean & Median & Mean & Median & Mean & Median & & & \\
\hline \multirow{5}{*}{$\begin{array}{l}\text { No mortgage debt } \ldots \ldots \\
\text { First mortgage only }{ }^{4} \ldots \\
\text { Home equity line } \\
\quad \text { of credit .......... } \\
\begin{array}{l}\text { Traditional home } \\
\text { equity loan } \ldots \ldots .\end{array} \\
\text { Memo } \\
\text { All homeowners ....... }\end{array}$} & 38 & 104,746 & 80,000 & 104,746 & 80,000 & 38,364 & 27,500 & 67 & 12 & 10 \\
\hline & 50 & 126,392 & 100,000 & 57,749 & 43,000 & 54,282 & 47,500 & 42 & 14 & 14 \\
\hline & 8 & 171,113 & 140,000 & 111,475 & 76,000 & 65,613 & 60,000 & 49 & 16 & 4 \\
\hline & 5 & 166,508 & 110,000 & 53,909 & 35,000 & 65,284 & 50,000 & 43 & 14 & 8 \\
\hline & 100 & 124,324 & 98,000 & 79,837 & 60,000 & 49,896 & 40,000 & 49 & 13 & 12 \\
\hline $\begin{array}{l}\text { Note. Data have been } \\
\text { sample. } \\
\text { 1. Market value of hon } \\
\text { ances outstanding on home }\end{array}$ & $\begin{array}{l}\text { e less all de } \\
\text { quity credit }\end{array}$ & $\begin{array}{l}\text { secured } \\
\text { es and tra }\end{array}$ & home, in & $\begin{array}{l}\text { ng bal- } \\
\text { y loans. }\end{array}$ & $\begin{array}{l}\text { 2. Ch } \\
\text { 3. Ch } \\
\text { 4. Exc } \\
\text { Sourc }\end{array}$ & $\begin{array}{l}\text { teristic o } \\
\text { teristic o } \\
\text { es those } \\
\text { Surveys }\end{array}$ & $\begin{array}{l}\text { d of hou } \\
\text { pondent. } \\
\text { have onl } \\
\text { nnsumers, }\end{array}$ & $\begin{array}{l}\text { ld. } \\
\text { home equ } \\
77 .\end{array}$ & line of cred & \\
\hline
\end{tabular}

from these groupings. The proportion of credit line holders with incomes of $\$ 75,000$ or more was substantially higher than that of any other group. A similar pattern holds for accumulated home equity, although, not surprisingly, many homeowners with no mortgage debt have also built up significant amounts of home equity. Levels of household income and home equity for holders of home equity lines are markedly higher than they are for holders of traditional home equity loans. Only 19 percent of borrowers with traditional home equity loans have incomes of $\$ 75,000$ or more, compared with 32 percent for holders of home equity lines; and only 10 percent of traditional home equity borrowers have $\$ 100,000$ or more in home equity, compared with nearly 40 percent for holders of home equity lines.

6. Homeowners, grouped by debt status and distributed by demographic and financial characteristics, 1997

Percent

\begin{tabular}{|c|c|c|c|c|c|c|}
\hline \multirow[b]{2}{*}{ Homeowner characteristic } & \multicolumn{6}{|c|}{ Homeowners } \\
\hline & All & $\begin{array}{c}\text { No mortgage } \\
\text { debt }\end{array}$ & $\begin{array}{c}\text { First mortgage } \\
\text { only }{ }^{1}\end{array}$ & $\begin{array}{l}\text { Home equity line } \\
\text { of credit }\end{array}$ & $\begin{array}{l}\text { Traditional } \\
\text { home equity } \\
\text { loan }\end{array}$ & $\begin{array}{l}\text { Either type } \\
\text { of home } \\
\text { equity loan }\end{array}$ \\
\hline \multirow{2}{*}{\multicolumn{7}{|c|}{ Age of head (years) }} \\
\hline & & 7 & 24 & 6 & 23 & 12 \\
\hline $35-44 \quad \ldots$ & 23 & 9 & 31 & 28 & 32 & 30 \\
\hline $\begin{array}{l}45-54 \\
55-64\end{array}$ & 20 & 12 & 24 & 34 & 27 & 31 \\
\hline $55-64 \ldots$. & 16 & 18 & 13 & 20 & 11 & 17 \\
\hline 65 or older. & 26 & 55 & 8 & 12 & 6 & 10 \\
\hline Total .. & 100 & 100 & 100 & 100 & 100 & 100 \\
\hline \multicolumn{7}{|l|}{ Family income (dollars) } \\
\hline Less than $15,000 \ldots \ldots$ & 10 & 20 & 4 & 2 & 2 & 2 \\
\hline $15,000-24,999 \ldots$ & 16 & 26 & 11 & 3 & 6 & 4 \\
\hline $25,000-49,999$ & 34 & 32 & 38 & 25 & 32 & 27 \\
\hline $50,000-74,999$ & 23 & 12 & 26 & 38 & 42 & 39 \\
\hline $75,000-99,999$ : & 10 & 5 & 13 & 16 & 8 & 14 \\
\hline 100,000 or more & 8 & 5 & 8 & 16 & 11 & 14 \\
\hline Total ........ & 100 & 100 & 100 & 100 & 100 & 100 \\
\hline \multicolumn{7}{|l|}{ Home equity $^{2}$ (dollars) } \\
\hline Less than $50,000 \ldots \ldots$ & 41 & 24 & 55 & 21 & 69 & 38 \\
\hline $50,000-99,999 \ldots$ & 33 & 38 & 29 & 40 & 21 & 34 \\
\hline 100,000 or more & 26 & 37 & 16 & 39 & 10 & 28 \\
\hline Total ........ & 100 & 100 & 100 & 100 & 100 & 100 \\
\hline \multicolumn{7}{|l|}{ Census region } \\
\hline West .......... & 17 & 14 & 18 & 18 & 27 & 21 \\
\hline North Central & 30 & 29 & 30 & 33 & 30 & 32 \\
\hline Northeast .... & 17 & 16 & 17 & 24 & 24 & 24 \\
\hline South .... & 36 & 42 & 35 & 25 & 19 & 23 \\
\hline Total & 100 & 100 & 100 & 100 & 100 & 100 \\
\hline \multicolumn{7}{|l|}{ Мемо } \\
\hline Percent of all homeowners & 100 & 38 & 50 & 8 & 5 & 13 \\
\hline
\end{tabular}

Note. Data have been weighted to ensure the representativeness of the sample.

1. Excludes those who have only a home equity line of credit.

2. Home equity consists of the market value of the home less all debts secured by the home, including balances outstanding on equity lines of credit and traditional home equity loans.

SOURCE. Surveys of Consumers, 1997. 
The relatively strong financial positions of households having home equity debt and especially lines of credit is reflected in banking industry statistics on loan delinquency rates (data not shown in tables). According to the American Bankers Association, fewer than 1 percent of home equity lines of credit at banks are typically in delinquent status, the lowest rate for any category of loan, and the delinquency rate on traditional home equity loans has averaged around $1 \frac{1 / 4}{4}$ percent recently, the second lowest figure of any loan category. By comparison, about $3 \frac{1}{2}$ percent of credit card accounts and personal loans were past due. When delinquency rates are based on dollar amounts rather than number of loans, the rates on home equity lines of credit and traditional home equity loans are both around 11/4 percent, still lower than for any other type of loan. In recent $A B A$ reports, a bit more than 5 percent of bank credit card debt was delinquent.

The survey data show some regional differences in the use of home equity products: Homeowners residing in the North Central region are the most likely to have a home equity loan, particularly a home equity line of credit. ${ }^{9}$ This geographic distribution differs from that in the 1993-94 survey, which found homeowners in the Northeast to be the most frequent holders of home equity loans. Change in the regional pattern may reflect the relatively strong growth in home prices (and hence, equity) in the North Central region during the period.

\section{Amounts Borrowed}

One important attraction of home-secured financing is that it allows homeowners to borrow relatively large amounts. In addition, as described below, many homeowners with lines of credit have substantial amounts available in the unused portions of their lines.

Users of home equity lines of credit and traditional home equity loans differ little in the amounts they have borrowed (table 7). On average, credit line users (that is, those who have an outstanding balance on their line of credit) owe only a bit more than users of traditional home equity loans, and the median amounts outstanding are the same.

9. The proportion of homeowners in the South with home equity loans may grow appreciably with recent amendments to the Texas State Constitution that significantly broaden the opportunities to offer traditional home equity loans in Texas. Home equity lines of credit, however, will still be prohibited in Texas. See John Trullinger, "Texas and Home Equity," Origination News (November 1997), pp. 4-5; and Heather Timmons, "Wary Lenders Brace for Texas Home Equity Flood," American Banker (January 14, 1998), p. 1.
The median balances on home equity loans are much larger than those on other forms of household debt. ${ }^{10}$ Nevertheless, most holders of home equity lines of credit owe an amount much smaller than their available credit line-for example, about 47 percent of those with a balance have less than 50 percent of their credit line in use. ${ }^{11}$ Among credit line holders with an outstanding balance, the mean and median proportions of the lines in use were around 55 percent, a level somewhat lower than in 1993-94. The lowering may be a reflection of refinancing activity in recent years, as some long-time users of home equity lines refinanced their outstanding balances on both their first and second mortgages into a single new loan.

\section{Purposes of Borrowing}

Historically, surveys have found that the principal uses for both types of home equity credit are

10. Median amounts owed on home equity loans are two to three times as large as those owed on installment debts and perhaps ten times as large as the median amount owed on credit cards. See Arthur B. Kennickell, Martha Starr-McCluer, and Annika E. Sunden, "Family Finances in the U.S.: Recent Evidence from the Survey of Consumer Finances," Federal Reserve Bulletin, vol. 83 (January 1997), pp. 1-24.

11. In addition, industry surveys indicate that for most home equity lines of credit the credit limit available may be increased with the approval of the lender. See Demong and Lindgren, "Home Equity Lending," p. 41.

7. Status of home equity debt, 1993-94 and 1997 Percent except as noted

\begin{tabular}{|c|c|c|c|c|}
\hline \multirow{2}{*}{ Item } & \multicolumn{2}{|c|}{ 1993-94 } & \multicolumn{2}{|c|}{1997} \\
\hline & $\begin{array}{l}\text { Lines } \\
\text { of credit }\end{array}$ & $\begin{array}{c}\text { Traditional } \\
\text { loans }\end{array}$ & $\begin{array}{l}\text { Lines } \\
\text { of credit }\end{array}$ & $\begin{array}{c}\text { Traditional } \\
\text { loans }\end{array}$ \\
\hline $\begin{array}{l}\text { Outstanding balance } \\
\text { (dollars) }\end{array}$ & & & & \\
\hline $1-9,999 \ldots \ldots \ldots \ldots$ & 34 & 42 & 35 & 29 \\
\hline $10,000-24,999$. & 38 & 40 & 35 & 48 \\
\hline 25,000 or more $\ldots \ldots$ & 28 & 19 & 30 & 23 \\
\hline Total .......... & 100 & 100 & 100 & 100 \\
\hline Meмo: Dollar balance & & & & \\
\hline Mean............. & 18,459 & 16,199 & 20,155 & 17,956 \\
\hline Median .............. & 15,000 & 11,000 & 15,000 & 15,000 \\
\hline $\begin{array}{l}\text { Percentage of credit } \\
\text { line in use }\end{array}$ & & & & \\
\hline $1-19 \ldots \ldots \ldots \ldots$ & 12 & $\ldots$ & 14 & $\cdots$ \\
\hline $20-49 \quad \ldots$ & 19 & & 33 & \\
\hline $50-74$ & 36 & & 23 & $\ldots$ \\
\hline $75-100$ & 33 & & 30 & $\cdots$ \\
\hline Мемо: In use (percent) & & & & \\
\hline Mean $\ldots \ldots \ldots \ldots \ldots$ & 58 & & 53 & $\ldots$ \\
\hline Median $. . . \ldots \ldots \ldots . . .$. & 62 & $\ldots$ & 55 & $\ldots$ \\
\hline
\end{tabular}

NotE. Measures for lines of credit exclude accounts with no outstanding balance. Data have been weighted to ensure the representativeness of the sample. . Not applicable.

Source. Surveys of Consumers, 1993-94 and 1997. 
8. Percentage of borrowers citing selected uses for home equity loan funds borrowed, by type of credit, 1993-94 and 1997

\begin{tabular}{|c|c|c|c|c|}
\hline \multirow{2}{*}{ Use } & \multicolumn{2}{|c|}{ 1993-94 } & \multicolumn{2}{|c|}{1997} \\
\hline & $\begin{array}{l}\text { Lines } \\
\text { of credit }\end{array}$ & $\begin{array}{c}\text { Traditional } \\
\text { loans }\end{array}$ & $\begin{array}{l}\text { Lines } \\
\text { of credit }\end{array}$ & $\begin{array}{c}\text { Traditional } \\
\text { loans }\end{array}$ \\
\hline Home improvement $\ldots .$. & 64 & 38 & 69 & 45 \\
\hline Repayment of other debts & 45 & 68 & 49 & 61 \\
\hline Education ............... & 21 & 4 & 19 & 2 \\
\hline Real estate ... & 12 & 8 & 9 & 10 \\
\hline Auto or truck & 30 & 3 & 37 & 6 \\
\hline Medical expenses & 5 & 1 & 10 & 2 \\
\hline Business expenses & 28 & 1 & 18 & 4 \\
\hline Vacation ........... & 6 & 1 & 13 & 1 \\
\hline Other $^{1}$.. & 1 & 3 & 1 & 1 \\
\hline
\end{tabular}

Note. Data have been weighted to ensure the representativeness of the sample. Percentages sum to more than 100 percent because respondents were allowed to cite multiple uses for a single loan or drawdown and more than one draw for one line of credit.

1. Includes purchase of furniture or appliance, purchase of boat or other recreational vehicle, payment of taxes, and personal financial investments.

SOURCE. Surveys of Consumers, 1993-94 and 1997.

to finance home improvements and to repay other debts. ${ }^{12}$ The results of the 1997 survey show a similar pattern (table 8); but credit lines were found to have additional uses not often found for most traditional loans, including vehicle purchases, education, and vacations. Both types of loan appear to be substitutes for various types of new or outstanding consumer credit.

\section{AGGREGATE HOME EQUITY DEBT}

After a period of anemic growth in the early 1990s, home equity debt began to expand again in 1994, with an increase in aggregate outstandings of about 6 percent. The pace has quickened substantially since

12. See Canner, Durkin, and Luckett, "Home Equity Lending: Evidence from Recent Surveys," p. 577; Lindgren and Demong, "Home Equity Loan Study," p. 15-16; and 1996 Home Equity Lines of Credit Survey Report (American Bankers Association, 1997), p. 88. then, climbing to an estimated 16 percent for 1996 and to just over 20 percent for 1997, lifting total home equity debt to an estimated $\$ 420$ billion at year-end (table 9).

\section{Influences on Growth}

Several factors suppressed the growth of home equity credit from 1991 through 1993. ${ }^{13}$ Stagnant real estate values in many localities were curbing the growth of equity in homes. As a result, fewer homeowners were becoming qualified for home equity credit, and those who did qualify may have been reluctant to increase their mortgage debt because of lowered expectations about future increases in home values. The 1990-91 recession no doubt also had a damping effect on home equity borrowing, indirectly by contributing to the sluggishness of home values and directly by affecting both the propensity of households to spend and their ability to qualify for credit.

Perhaps the greatest constraint on the growth of home equity loans, however, was the unprecedented surges in refinancings of first mortgage debt in the early 1990s, the first in 1992 and the second, even larger, in 1993, when mortgage interest rates fell to their lowest level in more than twenty years. As noted earlier, homeowners who refinanced while holding outstanding second-mortgage debt often folded that debt into the new first mortgage to lock in a low rate.

The moderation or reversal of these factors beginning in 1994 helps account for the recent resurgence of home equity borrowing. The economy's postrecession recovery was relatively listless in its early stages in 1992 and 1993, but it gained strength and

13. For a more detailed discussion of these influences, see Canner, Durkin, and Luckett, "Home Equity Lending: Evidence from Recent Surveys," pp. 580-82.

9. Home equity loans outstanding, grouped by year and distributed by type and source of credit, 1993-97 Billions of dollars

\begin{tabular}{|c|c|c|c|c|c|c|c|}
\hline \multirow{2}{*}{ Year } & \multicolumn{3}{|c|}{ Lines of credit } & \multicolumn{3}{|c|}{ Traditional loans } & \multirow{2}{*}{ Total } \\
\hline & $\begin{array}{l}\text { Commercial } \\
\text { banks }\end{array}$ & Other sources & All lenders & $\begin{array}{l}\text { Commercial } \\
\text { banks }\end{array}$ & Other sources & All lenders & \\
\hline 1993 & 73 & 37 & 110 & 49 & 102 & 151 & 261 \\
\hline 1994 & 76 & 40 & 116 & 54 & 104 & 158 & 274 \\
\hline 1995 & 79 & 44 & 123 & 61 & 115 & 176 & 299 \\
\hline 1996 & 85 & 47 & 132 & 69 & 146 & 215 & 347 \\
\hline 1997 & 98 & 55 & 153 & 76 & 191 & 267 & 420 \\
\hline
\end{tabular}

SOURCE. Reports of Condition and Income, various years; Credit Union National Association; Federal Reserve; Moody's Investors Service; and Bloomberg L.P. 
endurance over the four subsequent years. From the end of 1993 through last year, disposable personal income on average grew 5 percent per year, while the national unemployment rate dropped from 6.5 percent to 4.7 percent.

Home prices have also been on the rise again in most parts of the country. Although increases have been moderate compared with those in some earlier boom periods, they have helped boost the total value of the household sector's real estate holdings roughly 20 percent over the past four years. Refinancings of home mortgages have ebbed and surged during the period in tandem with fluctuations in mortgage interest rates, but the peaks in activity have fallen considerably short of the 1993 volume. ${ }^{14}$

\section{Emergence of the Subprime Market}

On the whole, then, recent macroeconomic developments have led to robust consumer spending, and strength in the real estate market has encouraged the use of home equity credit to finance part of that spending. Moreover, a new element has given a sharp boost to overall growth in home equity lending over the past couple of years, and that is the vigorous marketing by nonbank lenders to the "subprime" segment of the market-homeowners with relatively low incomes, limited equity, or tarnished credit histories. Loans in this higher-risk segment carry interest rates several percentage points higher than those on "A-quality" home equity loans and typically lift a borrower's total mortgage debt to a high level relative to the value of the home. Some subprime specialists offer to lend amounts that would raise that ratio to 125 percent, and in a few instances, even higher. ${ }^{15}$

Subprime home equity loans are commonly marketed as bill-consolidation loans, particularly as a means to pay off credit card debt. Given their pricing, collateral, and performance characteristicsrelatively high rates of charge-off and delinquency (chart 1) - these real-estate secured loans are more akin to unsecured personal loans than to mainstream home equity loans.

14. The decline in mortgage interest rates in the opening weeks of 1998, to just below 7 percent for conventional thirty-year fixed-rate loans, has spurred a surge in refinancing that may approach the earlier peak volume.

15. Generally speaking, however, industry sources indicate that most lenders who make so-called "125 loans" grant them only to borrowers of strong credit standing rather than to subprime borrowers. Such loans are higher in risk than A-quality mortgages because of the absence of equity, but borrower characteristics are typically well above average.
Most subprime lenders place heavy reliance on securitization of their loans to fund their operations. Through such means as third-party insurance guarantees or senior/subordinate debt structures, investors in the securities are largely insulated from credit losses; and the securities receive triple- $\mathrm{A}$ ratings, yielding returns of only 50 to 150 basis points above Treasury securities of comparable maturity. Ultimately, the home equity lenders bear the bulk of the credit risk, designed to be covered by the sizable margin between the interest rates paid by the subprime borrowers and the yield to the security holders.

\section{Lower Prepayment Risk}

One characteristic that has attracted investors to securities backed by home equity loans (generally subprime loans) is that, when interest rates drop significantly, the risk of accelerated prepayments of the loans underlying the securities has been considered to be less than for other mortgage-backed securities. ${ }^{16}$ When rates fall, borrowers in the subprime category are not expected to refinance so readily as other mortgagees precisely because their marginal credit status usually bars them from doing so at attractive interest rates.

16. When market interest rates fall significantly, many homeowners with existing mortgages will refinance, paying off the original loans. Under the typical "pass-through" security format, a large volume of mortgage prepayments means that principal is returned to investors sooner than anticipated, forcing them not only to reinvest earlier than planned but also in a low-rate environment.

1. Delinquency rates of traditional home equity loans, 1992-97

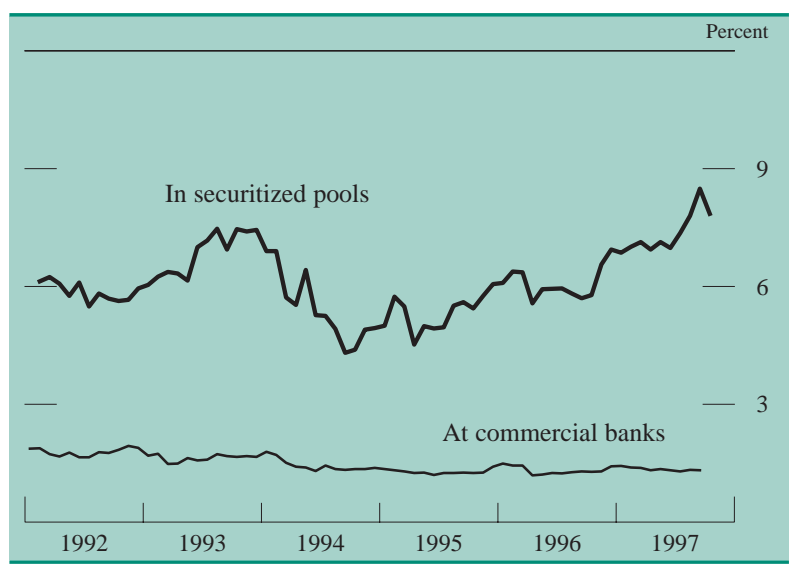

Note. Closed-end loans, typically second mortgages. The data are monthly. Source. For pools, Moody's Investors Service; for banks, American Bankers Association. 
Borrower reaction to the interest rate declines during the past year seems to support this expectation. A recent report from Standard \& Poor's observed that prepayments of securitized home equity loans have risen only slightly when interest rates have dropped sharply, while prepayments of other securitized mortgages have soared.17 Indeed, the principal factor behind home equity loan prepayments was found to be improvements in the financial positions of the borrowers that enable them to qualify for more attractively priced loans. ${ }^{18}$

\section{Volume in the Subprime Market}

The volume of subprime home equity credit cannot be estimated with much precision, in large part because definitional distinctions among different types of loans are not clear. With much of subprime home equity credit funded by securitization, an approximate measure of the volume of subprime credit can be derived from securitization volumes. But the loan pools designated as "home equity" pools frequently contain subprime purchase-money mortgages or refinanced loans as well; they may also mix some higher-quality home equity loans with the subprime paper. Conversely, not all subprime home equity loans are securitized. These imprecisions notwithstanding, however, data from industry sources suggest that the amount of home equity credit in securitized pools was about $\$ 90$ billion at the end of 1997, much of it believed to be subprime in quality (see box "Estimation of Aggregate Home Equity Debt"). This level represents about one-fifth of the estimated $\$ 420$ billion of aggregate home equity credit at yearend 1997.

\section{APPENDIX: THE SURVEYS OF CONSUMERS}

To obtain information on the prevalence of home equity accounts and their use by homeowners, the

17. "Standard Prepayment Model Doesn't Fit Home Equity Securities," National Mortgage News (November 24, 1997), p. 20.

18. Lately, however, prepayments for some pools of subprime home equity loans have been more rapid than anticipated in underwriting assumptions. These accelerated prepayments may imply that improvements in borrowers' financial positions have exceeded expectations or that intensified competition among lenders has enabled some lower-quality borrowers to refinance at rates below those they had originally obtained.

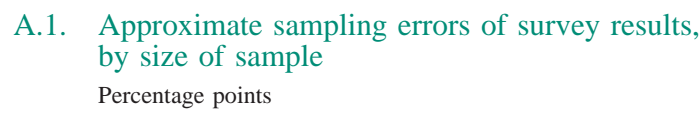

A.1. Approximate sampling errors of survey results, by size of sample

Percentage points

\begin{tabular}{c|r|r|c|c|c}
\hline \multirow{2}{*}{$\begin{array}{c}\text { Survey } \\
\text { results } \\
\text { (percent) }\end{array}$} & \multicolumn{5}{|c}{ Size of sample } \\
\cline { 2 - 6 } & 100 & 300 & 1,000 & 2,000 & 3,000 \\
\hline $50 \ldots \ldots \ldots$ & 10.5 & 6.2 & 3.6 & 2.8 & 2.5 \\
30 or $70 \ldots$ & 9.6 & 5.7 & 3.3 & 2.5 & 2.3 \\
20 or $80 \ldots$. & 8.4 & 4.9 & 2.9 & 2.2 & 2.0 \\
10 or $90 \ldots$. & 6.3 & 3.7 & 2.2 & 1.7 & 1.5 \\
5 or $95 \ldots \ldots$ & 4.6 & 2.7 & 1.6 & 1.2 & 1.1 \\
\hline
\end{tabular}

Note. Ninety-five percent confidence level, 1.96 standard errors.

Federal Reserve Board helped develop questions for inclusion in the Surveys of Consumers, conducted by the Survey Research Center of the University of Michigan, for the period May through October 1997. Interviewees were chosen from a cluster sample of residential listings, and the interviews were conducted by telephone. The sample was chosen to be broadly representative of the four major regionsNortheast, North Central, South, and West-in proportion to their populations (residents of Alaska and Hawaii were not included). For each telephone number drawn, an adult from the household was randomly selected as the respondent.

The survey defined a household as persons living together, whether or not related by marriage, blood, or adoption, or any individual living alone. The head of the household was defined as an individual living alone, the male of a married couple, or the adult (age eighteen or older) in a household composed of more than one person and only one adult. In the case of more than one adult but no married couple, the head of household generally was designated to be the person most familiar with the household's finances or the one closest to age 45 .

The survey included 3,000 households. Among the 2,098 respondents who were homeowners, 181 reported having a home equity line of credit, 102 reported having a traditional home equity loan, and 7 reported having both types. The survey data have been weighted to be representative of the population, thereby correcting for differences among households in the probability of their being selected as survey respondents. Estimates of population characteristics derived from samples are subject to error based on the degree to which the sample differs from the general population. Table A.1 indicates the sampling errors for proportions derived from samples of different sizes. 


\section{Estimation of Aggregate Home Equity Debt}

As banks and finance companies have reported more detailed information on their home equity loans in recent years, estimates of aggregate debt of this type have become more accurate. Other factors, however, have introduced new sources of imprecision into the estimates: the rapid development of securitization of home equity loans and the expanding role of mortgage companies and specialized home equity lenders, for whom data reporting is fragmentary.

Since 1987, commercial banks have reported receivables under home equity lines of credit on quarterly Call Reports, and since 1991 they have reported their holdings of traditional home equity loans. Mutual savings banks also report these data on Call Reports. Savings and loan associations and federal savings banks report credit line receivables on Call Reports but do not separate traditional home equity loans from first mortgages in these reports. Finance companies report each month to the Federal Reserve on their real estate loans, and since June 1996 they have reported residential and commercial mortgages separately. Finance companies do not distinguish between loans under lines of credit and traditional loans, but the bulk of their home equity receivables consists of traditional closed-end loans. Estimates of both types of home equity debt outstanding at credit unions are available from the Credit Union National Association.

\section{Debt Under Home Equity Lines of Credit}

According to Call Reports, commercial banks held about $\$ 98$ billion in receivables under home equity lines at the end of 1997 (table); savings institutions held about \$18 billion, and credit unions about $\$ 15$ billion. The data for the other holders are less precise. Information from the securities rating firms indicates that about $\$ 12$ billion of credit line receivables resided in pools of securitized assets (the data on these receivables usually do not show the type of originating institution).

The estimate of $\$ 10$ billion for finance companies is based on the fact that the household survey indicates that (1) they supplied only about 6 percent of the credit lines surveyed, (2) they reported $\$ 58$ billion of residential real estate credit at the end of 1997 , and (3) industry members confirm that most of these receivables are closed-end loans.

\section{Debt Under Traditional Home Equity Loans}

Estimating the amount of traditional home equity debt outstanding is somewhat more difficult: Fewer institutions provide specific data on this type of credit, and much of the recent growth has been among holders for whom the data are the least precise.

The Call Reports show the levels for commercial banks and credit unions.

Savings and loan associations and federal savings banks do not break out traditional home equity loans from their other residential mortgage debt. The household survey indicated that savings institutions (including mutual savings banks) held about half as much of this type of debt as commercial banks, which in 1997 would be about $\$ 38$ billion.

The estimate of $\$ 48$ billion for finance companies is derived from their report of $\$ 58$ billion in residential mortgage debt and the estimate that $\$ 10$ billion of it is in credit lines. The estimate for pools is from the rating agencies.

An estimate of $\$ 10$ billion is used here for miscellaneous sources of traditional loans, including mortgage companies. Although mortgage companies have become quite active in this market, most of the loans they originate are securitized and would be reflected in the estimate for pools.

The estimated $\$ 420$ billion of total home equity debt represents a 60 percent increase from the 1993 total, compared with an approximately 15 percent to 30 percent increase implied by responses to the household survey. Half the gain in the aggregate is accounted for by securitized loans, a category which, as noted, contains some unknown amount of loans that would otherwise be considered original or refinanced purchase-money mortgages. In the household survey, these loans were excluded from the detailed questions that focused on traditional home equity loans (typically second mortgages) and home equity lines of credit.

Estimates of aggregate home equity debt outstanding, by source, 1997

Billions of dollars

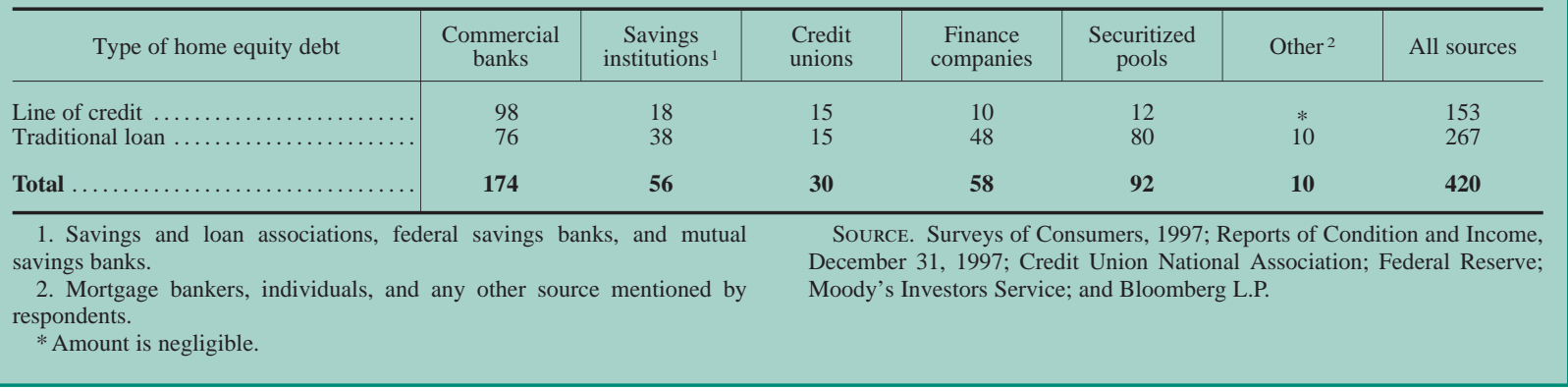

